\title{
The Virus that Changed Spain: Impact of COVID-19 on People with HIV
}

\author{
Rafael Ballester-Arnal ${ }^{1} \cdot$ Maria Dolores Gil-Llario ${ }^{2}$
}

Published online: 27 April 2020

(c) Springer Science+Business Media, LLC, part of Springer Nature 2020

Following the first outbreak of COVID-19 in Wuhan in December 2019, where Chinese authorities confirmed 41 cases detected between December 8 and January 2, 2020, the city stopped reporting cases until January 19 , when 17 more cases were confirmed. By then, the first cases of COVID-19 had been reported outside China: two in Thailand and one in Japan. The rapid spread of the disease led the World Health Organization to declare it an international health emergency on Jan. 30, 2020. By that date, COVID-19 had been detected in all provinces of mainland China and cases were reported in 15 other countries. On March 11, the disease was present in more than 100 territories worldwide and was recognized as a pandemic by WHO. The number of confirmed cases continued to grow and on April 12, the number of confirmed cases worldwide stands at 1,524,161, in Europe at 830,260 and in Spain at 161,852. Globally, the United States, Spain, and Italy thus far, have the highest number of diagnosed cases and the highest number of deaths.

The first patient in Spain diagnosed with the coronavirus was known January 31. He was a German patient admitted to the island of La Gomera (Canary Islands). Nine days later another case was detected on La Palma. But it was not until February 24 that the virus jumped to the peninsula, with the first cases being detected in the Communities of Madrid, Catalonia and Valencia. Although the progression and rate of infection that this disease has shown is remarkable, the good news is that so far in Spain, 59,109 people have recovered and the increase in diagnoses has stabilized, with a decrease in the growth of infections from 38 to $3 \%$. The bad news is, of course, that already 16,353 people have died from COVID-19 in Spain [1].

Rafael Ballester-Arnal

rballest@psb.uji.es

1 Departamento de Psicología Básica, Clínica y Psicobiología, Universitat Jaume I de Castellón, Castellón de la Plana, Spain

2 Departamento de Psicología Evolutiva y de La Educación, Universitat de Valencia, Valencia, Spain
According to the Competitiveness Index prepared by the 2019 World Economic Forum, Spain is the country with the best health system in the world, a privilege it shares with Singapore, Hong Kong and Japan, all of which have the highest score obtainable [2]. After Singapore and Japan, Spain has the longest healthy life expectancy on the planet. However, in spite of having a highly accessible public and universal health system, the COVID-19 epidemic has managed to collapse its services. Intensive Care Units have been overwhelmed by COVID-19 cases. Long working days without rest and with insufficient individual protection equipment have left a picture of thousands of health professionals infected and physically and mentally exhausted.

With an excellent Spanish health system, what explains the explosion of COVID-19 cases and its large spread in such a short time? Surely we must appeal to the central role played by the mildest and most asymptomatic cases in Spain. The first cases were not identified early, and individuals continued to unknowingly infect other people. As in other countries such as Italy and the United States, diagnostic tests began to be carried out in the population, although too late and only in cases where the symptoms were already severe. This made the coronavirus capable of infecting so many people without setting off alarms of the health authorities at the beginning of the epidemic. Surely the Latin and Mediterranean character of the Spanish people, a population that likes social closeness, parties, street life and physical contact through kisses and hugs, could also contribute to the rapid spread.

But in addition to these reasons, there were two other factors that had a negative impact, and which have to do with some features of this coronavirus. The first is its long incubation period: 2 to 14 days until symptoms are shown if they appear at all, and 5 to 7 days from the appearance of the first symptoms until patients develop more severe symptoms. And the second factor is that the clinical manifestations in mild cases ( $80 \%$ of cases) are similar to those of colds and flu. Unfortunately, the beginning of the COVID-19 epidemic in Spain coincided with the height of diseases typical of winter, that is people with COVID-19 but did not suspect 
it and unknowingly contributed to spread of the virus. In fact, it will take weeks or maybe months until we know how many Spaniards have been infected, and it may reach into the millions.

In view of the new pandemic, the Spanish government declared a state of alarm on 14th March for a fortnight, the maximum allowed by the Spanish Constitution. But subsequently the Congress of Deputies has twice extended this state of alarm, and it will most likely have to continue to be extended. The state of alarm, among other measures, forces the population to be confined to their homes, being able to go out only to go to the health services if it is essential, to supermarkets or pharmacies and to go to work if they are working in activities considered essential for society.

Death, suffering, fear, loneliness, desolation... the COVID-19 pandemic has had a devastating effect on Spanish society. It had been many decades, probably since the Spanish Civil War between 1936 and 1939, that Spanish society has suffered so much and in such a widespread way. The dead have been counted in thousands and it has reached a situation where it is actually a relief to hear that "only 500 " people have died in a single day because of the coronavirus, as if we have become numb to each death. But the worst thing is that this virus, which is ravaging our country and much of the world, is socially cruel, forcing people to lock themselves in their homes, preventing their loved ones from hugging each other, forcing them to keep their distance because each person has become a threat to others and is not even letting us accompany our dead in their burial. This effect of the epidemic may be even more difficult to bear in Spain where family ties are very strong, social life is very intense and there is a need to physically express affections. For this reason, the emotional wounds of this crisis will need a long time to heal and it is possible that when all this passes, Spanish society will be very different.

As is the case in every crisis and disaster, the most vulnerable populations are being most affected, namely people over 60 , with cardiovascular disease and high blood pressure, diabetes, chronic lung disease, cancer, immunosuppression, pregnancy and also people living or working in closed institutions, with special attention to older people living in residential homes. People living with HIV in Spain are among the most affected. From our research group, Salusex, and through our contact with Non-Governmental Organizations working in the field of HIV, we have been able to verify that people living with HIV are feeling threatened during this crisis. They are experiencing high levels of fear, anxiety and stress because of the possibility of being infected with another virus that could kill them. There is great concern over the lack of knowledge of how SARS-CoV-2 may synergize with HIV. People living with HIV are also concerned about access to HIV treatment. They don't know whether, in the face of the alarm and overcrowding of the health centers, they should go to the pharmacy to collect their antiretrovirals or whether it is dangerous to do so.

Although much is still unknown about this virus, early data suggests that people with HIV with a CD4 cell counts above 200 have the same risk for severe COVID-19 as people without HIV [3]. However, there are people with HIV who have a weaker immune system, which theoretically could be more vulnerable, especially those who are older and with poorer health. It is these variables and not having HIV that put them at greater risk [4, 5]. Given this greater vulnerability to COVID-19, going to a doctor's office, hospital, or pharmacy is dangerous for people living with HIV. For this reason, the work of many Non-Governmental Organizations includes going to the hospital to collect the treatment for people with HIV and delivering it to patient's homes. Other hospitals are having the treatment delivered by staff to these patients so that they do not have to leave their homes. There have not been problems with the supply of antiretrovirals to patients. Prescription drugs are generally being activated without a visit to the clinic, infectious disease consultations are usually done online, and treatment is being provided in larger supplies.

In this situation, it is important that people with HIV have adequate information and are neither overly alarmed nor overly confident, engage in positive health behaviors, especially optimal adherence to treatment. It is important for people with HIV to be informed that their vulnerability results from their overall health status, not by HIV per se. Excessive fear may cause some people with HIV to start a particular antiretroviral treatment or modify it for no reason.

Our Salusex research group is observing a considerable amount of misinformation, and there are disinformation campaigns, spreading fake news that can do much damage to the whole population and people with HIV in particular. Some of the most concerning myths circulating in Spain assure that the virus is less infectious in hot climates; that cold and snow kill the virus; that mosquitoes can transmit it; that the vaccine against the flu, antibiotics, hot water baths, the saline solutions to clean the nose, or even eating garlic prevent the infection; and that ultraviolet lamps or spraying the body with alcohol or chlorine cures infection. Fake news, as happened with the denialism in the HIV pandemic, constitutes a social irresponsibility, a health crime and a second epidemic where the lie is as dangerous as the physical spread of the virus.

Research is needed to investigate whether antiretroviral treatment adherence is improved or impeded by social isolation and confinement as well as other potential benefits or adverse impacts on the health of people with HIV. We also need to know how social confinement affects alcohol and other drug use. With regard to the groups that may be at greater sexual risk for HIV, there are not yet data on what the effect of confinement may be on sexual practices. 
Our Salusex group is finding that confinement may help to reduce the number of sexual contacts or at least the number of different people with whom these contacts are made. Sexual contact with sex workers and quick sex from contact apps may be altered. Sexual risks associated with the use of alcohol and other drugs as well as parties or large social events may also shift. In return, it is likely that online sexual activities are increasing with unknown implications. Finally, some people who are taking PrEP to protect them from HIV may erroneously believe that PrEP is also effective against COVID-19.

Some provisional data from a study that our research group is carrying out on the effects of COVID-19 on the sexual behavior of Spaniards indicates that in general sexual frequency has decreased in heterosexuals whereas same sex contacts have increased but this statement covers all types of sexual activity including masturbation and online sex, which has increased in people of all sexual orientations. On the other hand, we have found that a higher percentage of people who engage in same sex relations say they have skipped confinement to meet sex partners, with more than a third of general population considering that their sex life is worsening with this epidemic.

Without a doubt, for the entire Spanish population there will be before and after of the COVID-19 crisis period. After this epidemic, we will all have died a little bit. But it can also be a good opportunity to become more resilient, to get the best out of ourselves and to make valuable lessons, such as realizing that health is a collective good; the importance of solidarity and empathy; the cruelty of stigma, something that people with HIV unfortunately know a lot about; the treasure that is our older population to whom we owe so much; the importance of having a strong public health system and of caring for our health professionals, who are being applauded as heroes during this crisis; the value and fragility of life and the moral duty to enjoy it; and the privilege of being able to show our affection with a hug to our loved ones.

\section{El Virus que cambió España: impacto del COVID-19 en las personas con VIH}

Tras el primer brote de COVID-19 en Wuhan en diciembre de 2019, donde las autoridades chinas confirmaron 41 casos detectados entre el 8 de diciembre y el 2 de enero de 2020, la ciudad dejó de informar casos hasta el 19 de enero, cuando se confirmaron 17 casos más. Para ese entonces ya se habían reportado los primeros casos por COVID-19 fuera de China: dos en Tailandia y uno en Japón. La rápida expansión de la enfermedad hizo que la Organización Mundial de la Salud, el 30 de enero de 2020, la declarara una emergencia sanitaria a nivel internacional. En esa fecha, la enfermedad se había detectado en todas las provincias de China continental y se informaban casos en otros 15 países. El 11 de marzo la enfermedad se hallaba en más de 100 territorios a nivel mundial y fue reconocida como una pandemia por la OMS. El número de casos confirmados continuó creciendo y a fecha 12 de abril de 2020, el número de casos confirmados asciende en el mundo a 1.524.161, en Europa a 830.260 y en España a 161.852. A nivel mundial Estados Unidos, España e Italia son los países con más casos diagnosticados y con la cifra más alta de muertos.

El primer paciente en España con coronavirus se conoció el pasado 31 de enero. Fue un paciente alemán ingresado en la isla de La Gomera (Islas Canarias). Nueve días después se detectó otro caso coronavirus Covid-19 en la Palma. Pero no fue hasta el 24 de febrero cuando el virus saltó a la península, detectándose los primeros casos en la Comunidad de Madrid, Cataluña y la Comunidad Valenciana. A pesar de que la progresión y el ritmo de contagios que ha mostrado esta enfermedad es espectacular, la buena noticia es que hasta la fecha en España, 59.109 personas se han recuperado de ella y que el aumento de diagnósticos positivos parece haberse estabilizado en los últimos días, con una disminución del crecimiento de contagios del $38 \%$ en los primeros días al 3\% en la actualidad. La mala noticia es que ya 16,353 personas han fallecido por el COVID-19 en España [1].

Según el Índice de Competitividad elaborado por el Foro Económico Mundial relativo al año 2019, España es el país con la mejor sanidad del mundo, un privilegio que comparte con Singapur, Hong Kong y Japón, todos ellos con la máxima puntuación obtenible [2]. Quizás esto explique que tras Singapur y Japón, tenga la mayor esperanza de vida en salud del planeta. Sin embargo, a pesar de disponer de un sistema sanitario público y universal de gran prestigio, la epidemia del COVID-19 ha llegado a colapsar sus servicios. Las Unidades de Cuidados Intensivos se han visto desbordadas por la epidemia del COVID-19. Largas jornadas de trabajo sin descanso y con insuficientes equipos de protección individual han dejado un panorama de miles de profesionales sanitarios contagiados y agotados física y mentalmente.

Pero si el sistema sanitario español es tan bueno, ¿qué explica la explosión de casos de COVID-19 y su gran extensión en tan poco tiempo? Seguramente hay que apelar al papel central que tuvieron los casos más leves y asintomáticos en España. Esos casos no se identificaron tempranamente a través de pruebas a toda la población y mientras tanto seguían infectando a otras personas. $\mathrm{Al}$ igual que otros países como Italia y Estados Unidos se comenzó a realizar tests diagnósticos a la población demasiado tarde y solo en casos donde la sintomatología ya era acusada. Eso hizo que este virus fuera capaz de infectar a tantas personas sin disparar las alarmas de las autoridades sanitarias al comienzo de la epidemia. Seguramente a la rápida extensión pudo contribuir también el carácter latino y mediterráneo de los 
españoles, una población que gusta de la cercanía social, la celebración de fiestas, la vida en la calle y el contacto físico a través de besos y abrazos.

Pero además de estas razones, hubo otras dos que tuvieron un impacto muy negativo, y que tienen que ver con algunos rasgos de este coronavirus. El primero es su largo periodo de incubación: de 2 a 14 días hasta que se muestran los síntomas en el caso de que lleguen a aparecer y de 5 a 7 días desde que aparecen los primeros síntomas hasta que los pacientes desarrollan síntomas más graves. Y el segundo es que las manifestaciones clínicas en los casos leves (el $80 \%$ de los casos) son similares a las de las gripes y resfriados. Desafortunadamente, el comienzo de la epidemia de COVID-19 en España coincidió con la presencia entre la población de estas enfermedades características del invierno por lo que un alto porcentaje de personas que ya estaban infectadas, no lo sospecharon y nunca llegaron a ir a un centro de salud, aunque estaban contribuyendo a extender el virus. De hecho, harán falta semanas o quizás meses hasta que sepamos cuántos españoles han pasado ya el COVID-19 pero probablemente sean millones.

Este inicio de la epidemia hizo que el 14 de marzo el gobierno de España declarara el estado de alarma durante quince días, el máximo que permite la Constitución Española. Pero posteriormente el Congreso de los Diputados ha prorrogado dos veces este estado de alarma que estará vigente hasta el 26 de abril aunque lo más probable es que haya que volver a prorrogarlo. El estado de alarma, entre otras medidas, obliga al confinamiento de la población en sus hogares, pudiendo salir solo para acudir a los servicios sanitarios en el caso de que sea imprescindible, comprar en supermercados o farmacias e ir a trabajar en el caso de que se trabaje en las actividades consideradas esenciales para la sociedad.

Muerte, sufrimiento, miedo, soledad, desolación,... el COVID-19 ha provocado un efecto devastador en la sociedad española. Hacía muchas décadas, probablemente desde la Guerra Civil Española entre 1936 y 1939 que la sociedad española no sufría tanto y de una manera tan generalizada. Los fallecidos se han contado por miles y se ha llegado a una situación en la que ya es una alegría saber que solo 500 personas han fallecido en un solo día por el coronavirus, como si cada muerte no fuera un drama. Pero lo peor es que este virus, que está asolando nuestro país y gran parte del mundo, está siendo cruel en lo social, obligando a las personas a encerrarse en sus casas, impidiendo que los seres queridos se abracen entre sí, forzando a mantener las distancias porque cada persona se ha convertido en una amenaza para los demás y no nos está dejando ni acompañar a nuestros muertos en su entierro.

Este efecto de la epidemia todavía puede ser más difícil de sobrellevar en España donde los vínculos familiares son muy fuertes, la vida social muy intensa y existe una necesidad de expresar físicamente los afectos. Por ello, las heridas emocionales de esta crisis necesitarán mucho tiempo para ser curadas y es posible que, cuando todo esto pase, la sociedad española sea otra muy distinta.

Como sucede en toda crisis y catástrofe, la población más vulnerable está siendo la más afectada, concretamente las personas de más de 60 años, con enfermedades cardiovasculares e hipertensión arterial, diabetes, enfermedades pulmonares crónicas, cáncer, inmunodepresión, embarazo y también las personas que viven o trabajan en instituciones cerradas, con especial atención a las personas mayores que viven en residencias. Las personas que viven con el VIH en España se encuentran entre ese colectivo. Desde nuestro grupo de investigación Salusex y a través de nuestro contacto con Organizaciones No Gubernamentales que trabajan en el ámbito del VIH, hemos podido comprobar que estas personas se están sintiendo más amenazadas durante esta crisis. Están experimentando altos niveles de miedo, ansiedad y estrés por la posibilidad de contagiarse con un virus que les pueda matar, por el desconocimiento de cómo puede influir el SARS-CoV-2 al tener el VIH. Pero también están preocupados por el acceso a los tratamientos. No saben si ante el estado de alarma y de sobresaturación y desbordamiento de los centros sanitarios, pueden ir a la farmacia del hospital para recoger sus antirretrovirales, si deben ir a la consulta médica o si resulta peligroso hacerlo y es mejor quedarse en sus casas.

Aunque todavía se desconoce mucho de este virus, los datos nos indican que hasta la fecha las personas con VIH con un número de linfocitos por encima de 200 CD4, tienen el mismo riesgo y la misma evolución que las personas que no tienen VIH [3]. Sin embargo, hay personas con VIH que están con un sistema inmunitario más débil, que teóricamente podrían ser más vulnerables, especialmente los que tengan una mayor edad y un peor estado de salud. Son estas variables y no tener el VIH, las que les colocan en una situación de mayor riesgo $[4,5]$. Ante esta situación de mayor vulnerabilidad, acudir a consulta médica o a recoger su medicación en el hospital o saltarse las medidas que todo ciudadano tiene que tomar para prevenir el COVID-19 podría ser más peligroso para ellos. Por ello, está siendo encomiable el trabajo de muchas Organizaciones No Gubernamentales que están acudiendo al hospital para recoger el tratamiento de personas con VIH y llevárselo a sus casas. Otros hospitales están enviando por mensajería el tratamiento a estos pacientes para que no tengan que salir de sus hogares. No está habiendo problemas de abastecimiento de antirretrovirales para los pacientes. La receta farmaceútica se está activando generalmente sin pasar presencialmente por consulta, la consulta de enfermedades infecciosas se suele hacer online en la mayoría de los casos, y se facilita el tratamiento para mas tiempo en algunos casos.

Ante esta situación, es importante que las personas con VIH tengan información adecuada y no estén ni 
excesivamente alarmados ni tampoco confiados, es decir, conseguir que tengan una adecuada conducta de enfermedad y especialmente una buena adherencia al tratamiento. Es importante que las personas con VIH sepan que frente a la amenaza del COVID-19 la vulnerabilidad se la dará su estado de salud global, no el VIH. El que tengan un temor excesivo e irracional puede hacer que algunas personas con VIH inicien un tratamiento antirretroviral determinado o lo modifiquen sin motivo, tomando otros fármacos o aumentando la dosis peligrosamente.

Desde Salusex estamos comprobando que existe mucha desinformación y algo muy importante, algunas personas se están dedicando a extender fake news que pueden hacer mucho daño a toda la población y a ésta en particular. Algunas de las más curiosas aseguran que el contagio es menor en climas cálidos; que el frío y la nive matan el virus; que los mosquitos pueden transmitirlo; que la vacuna contra la gripe, los antibióticos, los baños de agua caliente, las soluciones salinas para limpiar la nariz, o incluso comer ajo previenen el contagio; y que las lámparas ultravioleta o rociar el cuerpo con alcohol o cloro mata al virus aunque ya haya entrado en el organismo. Las fake news, al igual que sucedió con el negacionismo en la pandemia del VIH, constituye una irresponsabilidad social, un delito sanitario y una segunda epidemia donde la mentira resulta tan peligrosa como la extensión física del virus.

$\mathrm{Al}$ margen de la adherencia al tratamiento antirretroviral, aunque no disponemos todavía de datos empíricos publicados, es bastante probable que la situación de confinamiento esté teniendo algunos beneficios en los hábitos de salud de algunas personas con VIH, especialmente en aquellas que tienen un consumo abusivo del alcohol y de otras drogas, que habrían disminuido su accesibilidad. Y también el número de reinfecciones al no poder entrar en contacto físico con otras personas fuera de su hogar.

Por lo que respecta a los colectivos que pueden estar en una mayor situación de riesgo frente al VIH por sus prácticas sexuales, aún no disponemos de datos científicos sobre cuál puede ser el efecto del confinamiento en estas prácticas. Pero por las informaciones que nos llegan a nuestro grupo Salusex, es posible que el confinamiento puede ayudar a disminuir el número de contactos sexuales de riesgo o al menos el número de personas distintas con las que se realizan estos contactos. También el contacto sexual con trabajadores del sexo y las relaciones rápidas a partir de las apps de contactos. Y lo mismo sucede con las actividades sexuales de riesgo asociadas al consumo de alcohol y otras drogas en el marco de fiestas o grandes eventos sociales. A cambio, es bastante probable que estén aumentando las actividades sexuales online. No obstante, es posible que algunas personas que ni siquiera están realizando prácticas de riesgo para el VIH, estén tomando innecesariamente la PrEP pensando que va a ser efectiva contra el COVID-19.
Algunos datos provisionales de un estudio que nuestro grupo de investigación Salusex está realizando sobre los efectos de esta epidemia en la conducta sexual de los españoles nos indican que en general ha disminuido la frecuencia sexual en los heterosexuales y se ha incrementado en la población no heterosexual, pero en esta afirmación se engloba todo tipo de actividad sexual incluida la masturbación y el sexo online, que ha aumentado en personas de cualquier orientación sexual. Por otro lado, hemos encontrado que un porcentaje mayor de no heterosexuales que de heterosexuales dice haberse saltado el confinamiento para tener relaciones con otras personas. Pero en lo que no hay diferencias es en que más de un tercio considera que su vida sexual ha empeorado con esta epidemia.

Sin ninguna duda, para toda la población española habrá un antes y un después del COVID-19. Después de esta epidemia, todos habremos muerto un poco. Pero también puede ser una buena ocasión para hacernos más resilientes, para sacar lo mejor de nosotros mismos y realizar aprendizajes valiosos, como darnos cuenta de que la salud es un bien colectivo; la importancia de la solidaridad y la empatía; la crueldad que supone cualquier estigma, algo de lo que las personas con VIH desgraciadamente saben mucho; el tesoro que supone nuestra población más mayor a la que tanto le debemos; la importancia de tener una robusta sanidad pública y de cuidar de nuestros profesionales sanitarios, que están siendo aplaudidos como héroes durante esta crisis; el valor y la fragilidad de la vida y el deber moral de disfrutarla; y el privilegio que supone poder demostrar nuestro afecto con un abrazo.

\section{References}

1. GeSIDA. 2020. Información general de GeSIDA sobre COVID19 y VIH. https://mail.google.com/mail/u/0/\#search/jancho/QgrcJ HsNjqPzpQsGQTxZVzktzKzhzwPtbwB? projector=1\&messa gePartId=0.1. Accessed 12 April 2020.

2. Gobierno de España. Ministerio de Sanidad. 2020. https://covid 19.iscii.es/. Accessed 12 April 2020.

3. World Economic Forum. 2019. The Global Competitiveness Report. https://www3.weforum.org/docs/WEF_TheGlobalCompet itivenessReport2019.pdf. Accessed 12 April 2020.

4. Gobierno de España. Ministerio de Sanidad. 2020. https://www. mscbs.gob.es/profesionales/saludPublica/ccayes/alertasActual/ nCov-China/documentos/20200404_ITCoronavirus.pdf. Accessed 12 April 2020.

5. Sociedad Española de Inmunología. 2020. Recomendaciones para la prevención frente al coronavirus SARS-CoV-2 en pacientes inmunodeprimidos. https://www.omsida.org/wp-content/uploa ds/2020/03/Sociedad_Espa\%C3\%B1ola_Inmunologia.pdf. Accessed 12 April 2020.

Publisher's Note Springer Nature remains neutral with regard to jurisdictional claims in published maps and institutional affiliations. 